\title{
Controlling environmental factors of soil enzyme activities at three altitudes on Mt. Jumbong
}

\section{Inyoung Jang and Hojeong Kang*}

School of Civil and Environmental Engineering, Yonsei University, Seoul 120-749, Korea

Soil microbes perform crucial roles in the nutrient cycles of forest ecosystems, by effecting the decomposition of organic matter. Enzyme activities have been used to evaluate decomposition rates, as well as microbial activities. The principal objectives of this study were to determine the activities of different soil enzymes, to compare enzyme activities at different elevations, and to elucidate the most important controlling variables for enzyme activities. We conducted a field survey at three sites in Mt. Jumbong on a monthly basis from May, 2004 to September, 2005. Enzyme activities did not change substantially over different seasons. However, the spatial differences were distinct; the lowest elevation site evidenced the lowest levels of enzyme activity. Soils at the lowest elevation were nutrient-depleted soils, and enzyme activities appeared to be affected by precipitation and temperature. However, enzyme activities in fertile soils at high elevations were associated with nutrients and organic matter. The enzyme activities detected in this study differed significantly at the three elevations, and their controlling variables also evidenced different factors.

Key words: controlling factors, enzyme activities, forest soil, spatial variations

\section{INTRODUCTION}

Soil microbes perform key functions in the nutrient cycles of forest ecosystems by effecting the decomposition of organic matter. The decomposition of plant litter on the forest floor is a critically important process for the integration of organic matter into humus. This is also relevant to the biogeochemical cycles of elements including carbon, nitrogen, phosphorus, and sulfur. Microorganisms can mineralize up to $80 \%$ of dead plant materials (Waring and Schlesinger 1986). As the importance of soil microbes has become increasingly recognized, many previous studies have been conducted in this regard including studies about the key variables controlling soil microbial activities. Temperature, $\mathrm{pH}$, soil water content, land use changes, and nutrient availability have been identified as key variables controlling soil microbial activities (Kang and Lee 1998, Andersson and Nilsson 2001,
Allison et al. 2008, Ye et al. 2009). According to our manipulation experiment, $\mathrm{Q}_{10}$ varied from 1.4 to 3.3 with different latitudes and types of soils (Winkler et al. 1996, Hopkins et al. 2006, Jin et al. 2008). Many studies have emphasized not only temperature but also soil water content as key controlling variables on microbial activities (Orchard and Cook 1983, Stark and Firestone 1995, Kang et al. 2003, Jia et al. 2006). Soil nutrients such as carbon, nitrogen, and phosphorous have also been identified as factors important to microbial activities (Wright and Reddy 2001, Jordan et al. 2003, Enowashu et al. 2009).

Microbial activity in soils can be estimated via respiration, arginine ammonification, or molecular tools such as stable isotope probing or enzyme activities (Paul and Clark 1989). Among these methods, enzyme activity analysis has been employed by a variety of researches. (cc) This is an Open Access article distributed under the terms of the Creative Commons Attribution Non-Commercial License (http://creativecommons.org/licenses/by-nc/3.0/) which permits unrestricted non-commercial use, distribution, and reproduction in any medium, provided the original work is properly cited.
Received 17 March 2010, Accepted 31 March 2010

${ }^{*}$ Corresponding Author

E-mail: hj_kang@yonsei.ac.kr

Tel: +82-02-2123-5803 
Enzyme activities are influenced by microbial community structures (Waldrop et al. 2000, Kourtev et al. 2002), biomass (Zak et al. 1994, Kennedy and Gewin 1997, Wellington et al. 2003) and physico-chemical properties of soil (Halvorson et al. 1996, Speir and Ross 2002). Therefore, enzyme activities are frequently utilized to evaluate the ecological integrity of soils, and as a general indicator of microbial activity (Killham and Staddon 2002).

The principal objectives of this study were: 1) to estimate soil enzyme activities of different types of extracellular enzyme activities in temperate forest soils, 2) to compare activities measured at different elevations, and 3) to determine key environmental factors for enzyme activities at different elevations.

\section{MATERIALS AND METHODS}

\section{Study site}

This study was conducted on Mt. Jumbong (38 $02^{\prime} \mathrm{N}$, $128^{\circ} 26^{\prime}$ E) in South Korea. Mt. Jumbong is a hardwood forest zone located at the southernmost outside area of the Mt. Seorak national park in Kangwon Province. The site is part of a UNESCO Biosphere Reserve and has been designated as a Natural Forest Reserve by the Korea For- est Service, Korea. The dominant fauna in this area are Quercus mongolica and Acer pseudo-sieboldianum. The annual average temperature is $6.3^{\circ} \mathrm{C}$ and the annual precipitation is $1,578 \mathrm{~mm}$ (Kang et al. 2003). Soil samples were collected at 3 different locations with different elevations (Table 1). The soil in this area is classified as sandy clay loam (sand, $49 \%$; silt, $24 \%$; clay, $27 \%$ ).

\section{Soil physico-chemical analysis}

Soil samples for chemical and enzyme analysis were collected from May, 2004 to September, 2005 on a monthly basis. Two replicate soils were collected at each site using a soil corer (5 cm dia. $\times 5 \mathrm{~cm}$ height) after removing the surface litter layer. Samples were transferred to a lab on ice, then sieved $(2 \mathrm{~mm})$ to remove large debris and stones.

Soil water contents were measured via oven-drying at $105^{\circ} \mathrm{C}$ and the organic matter contents were determined via loss on ignition at $600^{\circ} \mathrm{C}$. The $\mathrm{pH}$ levels were determined by a $\mathrm{pH}$ meter after mixing with distilled water and settling (soil:water $=1: 2$ ). DOC was extracted with distilled water and filtered through a $0.45 \mu \mathrm{m}$ filter, and then analyzed via a TOC analyzer (TOC-V $\mathrm{CPH}_{\mathrm{CP}}$; Shimadzu, Tokyo, Japan). Ammonium was determined via the indophenol blue method after extraction with $2 \mathrm{M} \mathrm{KCl} \mathrm{(Kee-}$

Table 1. Spatial variations of average soil physico-chemical properties over 2 years ( $N$ : 34 for each site)

\begin{tabular}{|c|c|c|c|}
\hline & Site 1 & Site 2 & Site 3 \\
\hline Altitude (m) & 740 & 895 & 1066 \\
\hline Dominant plant species & Acer pseudo-sieboldianum & Pinus koraiensis & Quercus mongolica \\
\hline Water content $(\%)$ & $33.81(9.03)^{\mathrm{a}}$ & $40.53(14.31)^{\mathrm{b}}$ & $44.18(9.21)^{\mathrm{b}}$ \\
\hline Organic content (\%) & $15.06(6.89)^{\mathrm{a}}$ & $20.51(9.53)^{\mathrm{ab}}$ & $24.45(15.90)^{\mathrm{b}}$ \\
\hline $\mathrm{pH}$ & $4.8(0.5)^{\mathrm{a}}$ & $5.5(0.6)^{\mathrm{b}}$ & $5.0(0.7)^{\mathrm{a}}$ \\
\hline DOC (mg/g dry soil) & $0.10(0.04)^{\mathrm{a}}$ & $0.13(0.15)^{\mathrm{a}}$ & $0.12(0.07)^{\mathrm{a}}$ \\
\hline Total carbon (\%) & $4.26(0.18)$ & $6.44(1.77)$ & $8.20(2.94)$ \\
\hline $\mathrm{NH}_{4}^{+}(\mu \mathrm{g} / \mathrm{g}$ dry soil $)$ & $29.59(23.53)^{\mathrm{a}}$ & $23.48(28.17)^{\mathrm{a}}$ & $29.45(23.88)^{\mathrm{a}}$ \\
\hline $\mathrm{NO}_{3}^{-}(\mu \mathrm{g} / \mathrm{g}$ dry soil $)$ & $3.76(2.54)^{\mathrm{a}}$ & $9.50(9.01)^{\mathrm{b}}$ & $16.89(8.60)^{\mathrm{c}}$ \\
\hline Total nitrogen (\%) & $0.27(0.01)$ & $0.49(0.12)$ & $0.64(0.22)$ \\
\hline Total phosphorus (\%) & $0.088(0.078)$ & $0.132(0.008)$ & $0.083(0.071)$ \\
\hline Extractable $\mathrm{K}^{+}(\mathrm{mg} / \mathrm{kg})$ & $48.85(53.67)$ & 274.25 (21.28) & $225.45(85.77)$ \\
\hline Extractable $\mathrm{Ca}^{2+}(\mathrm{mg} / \mathrm{kg})$ & $115.3(50.3)$ & $1650.5(983.6)$ & $1974.5(528.2)$ \\
\hline Extractable $\mathrm{Mg}^{2+}(\mathrm{mg} / \mathrm{kg})$ & $27.7(5.7)$ & $165.1(66.1)$ & $227.1(83.6)$ \\
\hline Temperature $\left({ }^{\circ} \mathrm{C}\right)$ & $11.16(7.82)^{\mathrm{a}}$ & $9.44(8.28)^{\mathrm{a}}$ & $11.64(6.98)^{\mathrm{a}}$ \\
\hline
\end{tabular}

Standard deviation are given in parentheses.

${ }^{a, b}$ Significant differences. 
ney and Nelson 1982). Nitrate was extracted with $0.5 \mathrm{M}$ $\mathrm{K}_{2} \mathrm{SO}_{4}$ and measured by a colorimetric method (Anderson and Ingram 1993). Soil temperatures were measured with a soil thermometer. The data regarding precipitation and snow depth in this region were obtained from the Inje weather station, which is the nearest weather station.

\section{Measurements of enzyme activities}

Methylumbellifery (MUF)-substrates were employed as model substrates for soil enzymes. MUF-ß-D-glucoside, MUF- $\mathrm{N}$-acetylglucosaminide, MUF-phosphate and MUF-sulfate were used for B-glucosidase, $\mathrm{N}$-acetylglucosaminidase, phosphatase, and arylsulfatase, respectively. $1.5 \mathrm{~g}$ soil samples were amended with $5 \mathrm{~mL}$ of substrate $(400 \mu \mathrm{mol})$. After 60 minutes of incubation at $20^{\circ} \mathrm{C}$, fluorescence in the supernatant was determined using a TD-700 fluorometer with a $450 \mathrm{~nm}$ emission and 330 $\mathrm{nm}$ excitation wavelength. For each sample, a calibration curve was prepared using 0-200 $\mu \mathrm{mol}$ of MUF-free acid, which was used due to its quenching effects and soil absorption properties (Kang and Freeman 1999).

\section{Statistical analysis}

To evaluate differences among the sites and sampling periods, data were analyzed via one-way ANOVA. Nonparametric correlation was employed to determine the relationship between environmental factors and methane oxidation rates. In an effort to model the relationship between methane oxidation rates and other environmental factors, we utilized a multiple linear regression model employing a stepwise regression algorithm. We conducted stepwise analysis with the average values of normalized enzyme activities and environmental factors. We normalized the glucosidase, $\mathrm{N}$-acetylglucosaminidase and phosphatase by averaging them in accordance with the method of Kang and Freeman (2009). All analyses were conducted with SPSS ver. 12.0 (SPSS Inc., Chicago, IL, USA). The results were considered to be statistically significantly different at $P<0.05$.

\section{RESULTS AND DISCUSSION}

\section{Soil characteristics}

The $\mathrm{pH}$ of these soils varied between 4.8 and 5.5. Many of the soil properties in site 1 are different from those of sites $2 \& 3$. Although sites $2 \& 3$ were shown to differ in terms of their dominant vegetation, they evidenced similar chemical properties. Soil water contents, organic matter contents, and nitrate contents were significantly higher in sites $2 \& 3$ than in site 1 (Table 1 ).

\section{Seasonal differences of enzyme activities}

Mean values of $\mathrm{B}$-glucosidase, $\mathrm{N}$-acetylglucosaminidase, phosphatase, and arylsulfatases were 71.65, 22.59, 103.28 , and $28.88 \mathrm{nmol} \mathrm{g}^{-1}$ dry soil $\mathrm{min}^{-1}$, respectively. These values were similar to those measured in other temperate forest soils (Harrison 1983, Speir and Cowling 1991, Trasar-Cepeda et al. 2000) and were slightly higher than in cold areas (Haussling and Marschner 1989). ßglucosidase and phosphatase evidenced higher levels of activity than $\mathrm{N}$-acetylglucosaminidase and arylsulfatase. We noted no significant seasonal variations in $\beta$-glucosidase, $\mathrm{N}$-acetylglucosaminidase, or phosphatase; those enzyme activities evidenced similar values throughout the entire year, even during the winter. However, arylsulfatase evidenced a marked seasonality pattern, with much higher values in summer than in winter (data not shown). This is consistent with the results of a previous study (Kang and Freeman 1999). Acosta-Martínez et al. (2007) also noted that arylsulfatase exhibits a different origin from other enzymes, and may be controlled in a different manner. Other enzymes may be influenced by other factors such as the organic matter supply (Vance and Chapin 2001) and water availability. As a consequence, those enzyme activities may not evidence peak activity levels over the summer (Bonnett et al. 2006). Further, the method utilized in this study was conducted using saturated concentrations of substrates and optimal temperatures. As such, this method provided potential

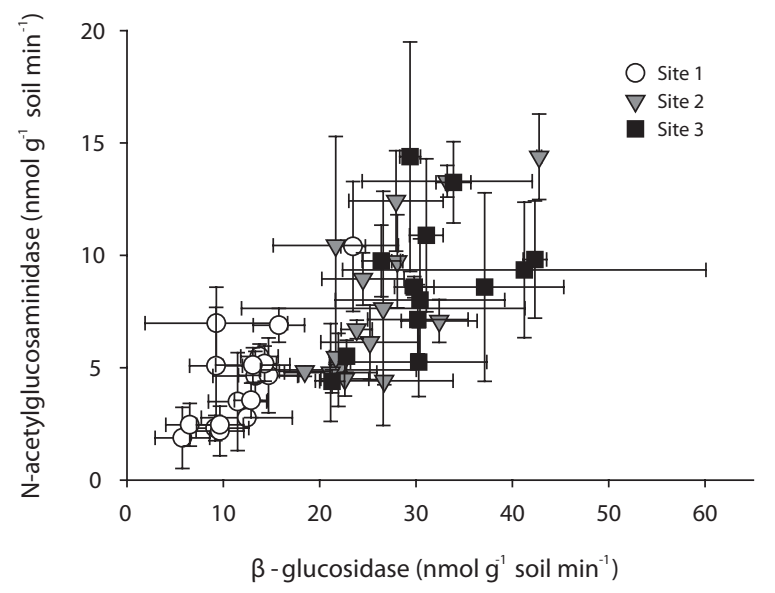

Fig. 1. B-glucosidase and $\mathrm{N}$-acetylglucosaminidase activities at three sites over 2 years. 
activities rather than actual activities, that may be influenced profoundly by temperature and edaphic conditions.

Interestingly, the ratio between different enzymes is consistent over seasons and sites. Fig. 1 shows a similar ratio between $ß$-glucosidase and $\mathrm{N}$-acetylglucosaminidase in different sites and on different months. This is consistent with a report from Sinsabaugh et al. (2009) who noted similar scaling of $\mathrm{C}, \mathrm{N}, \mathrm{P}$ acquisition enzymes across a variety of ecosystems. Although substantial variations of enzyme activities were noted on a small scale, the overall enzyme ratios may remain constant.

\section{Spatial differences of enzyme activities}

The enzyme activities in sites $2 \& 3$ were significantly higher than those of site 1 for every enzyme. In particular, ß-glucosidase and $\mathrm{N}$-acetylglucosaminidase clearly evidenced these trends (Fig. 1). Additionally, phosphatase levels were significantly different at every site (data not shown). For every enzyme activity, the values in site 3 are higher than those in site 1 .

We conducted correlation analysis separately for each site. Because there were no significant seasonal differences, we composited the data and analyzed it with different sites, and thus the numbers of data collected were 34 and 62 for site 1 and sites $2 \& 3$, respectively. The $ß$ glucosidase, $\mathrm{N}$-acetylglucosaminidase, and phosphatase activities measured at site 1 were significantly correlated with organic matter contents $(r=0.467, P=0.005 ; r=$ $0.362, P=0.036$ and $r=0.484, P=0.004$, respectively) and temperature ( $r=0.376, P=0.028$ and $r=0.553, P=0.001$, respectively), but arylsulfatase was associated with $\mathrm{pH}(r$ $=-0.364, P=0.034$ ) (Fig. 2). Thirty-eight percent of variations in average enzymes could be explained by temperature and organic content, the regression equation of

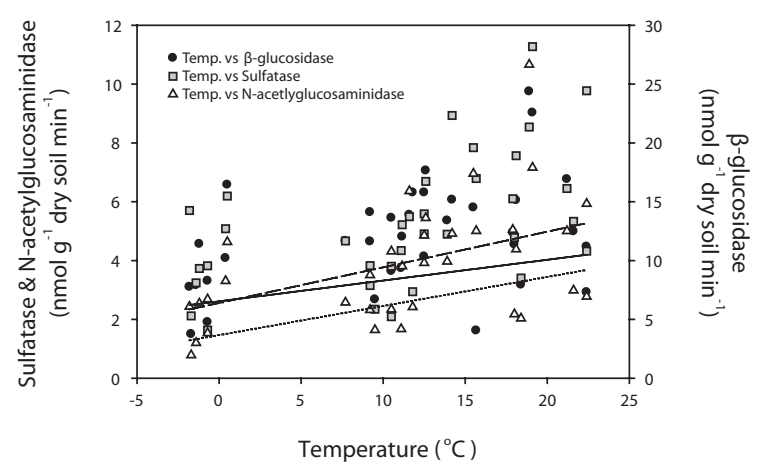

Fig. 2. Correlation analysis between enzyme activities and temperature at site 1 . which is as follows;

Enzyme activities $=0.013 \times$ Temperature $+0.12 \times$ Organic matter content +0.326

On the other hand, the values at sites $2 \& 3$ were significantly correlated with water content $(r=0.675,0.591$, and 0.406; $P<0.001$ ), organic matter contents ( $r=0.599$, $0.481,0.349$, and $0.384 ; P<0.05$ ) and inorganic nitrogen ion content ( $r=0.343-0.548, P<0.05$ ) (Fig. 3). The following regression equation explained $56 \%$ of the variations in average enzyme activities.

Enzyme activities $=25.864 \times \mathrm{NO}_{3}{ }^{-}+0.014 \times$ water content $+5.701 \times \mathrm{NH}_{4}^{+}+0.140$

Enzyme activities differed significantly among the sites in our study. These differences were particularly distinctive between site 1 and sites $2 \& 3$. Importantly, the dominant tree species of these locations were different. The dominant species in sites 1 and 3 were deciduous forest, and conifers were dominant at site 2. Despite this difference in tree species, the enzyme activities differed between site 1 and sites $2 \& 3$. Therefore, the soil properties appear to be more salient than the predominating tree species. This was consistent with the conclusions of Ushio et al. (in press). They concluded that soil physicochemical properties were critically important to enzyme activities. Although the tree species affect the physicochemical properties of soil, the properties of soil may have a more direct effect on enzyme activities. The enzyme activities evidenced significantly higher values in sites $2 \& 3$ than in site 1 . The results of regression analyses also demonstrated different controlling variables between site 1 and sites $2 \& 3$. The physico-chemical properties of soil, such as organic matter contents, ex-

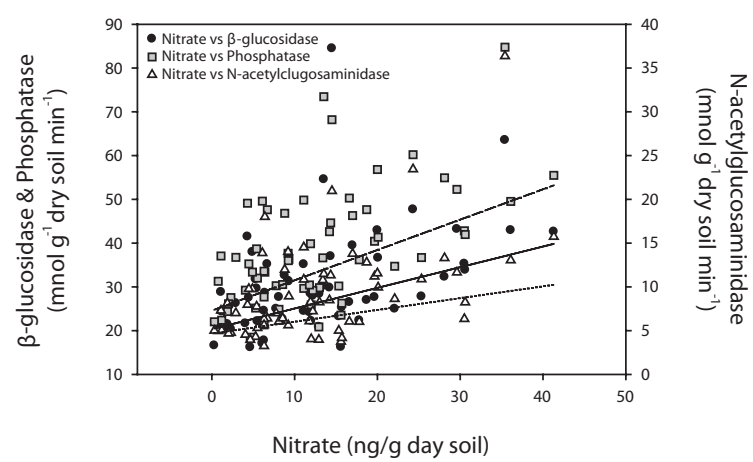

Fig. 3. Correlation analysis between enzyme activities and nitrate at sites 2 \& 3 
changeable cation, nitrate, and ammonium ion contents were higher at higher elevations. It has been suggested that enzyme activities in site 1 , which is characterized by low nutrient availability and organic matter contents, are strongly controlled by temperature (Fig. 2). By way of contrast, enzyme activities in fertile soils in sites 2 \& 3 are more profoundly influenced by nitrogen availability (Fig. 3). Enzyme activities have been reported to be strongly affected by microclimates in degraded soils. For example, Boerner et al. (2005) reported that different types of enzymes evidenced different relationships with abiotic factors in degraded soils, such as thinning and fired soils. For example, chitinase and acid phosphatase contents were regulated by microclimate, whereas lignocellulosedegrading enzymes were affected most prominently by substrate availability. The overall results of this study show that soil fertility characteristics may impose controls on soil enzyme activities and influence key controlling variables.

\section{ACKNOWLEDGMENTS}

This study was supported by funds from the NRF (2009-0092795), KOSFE (F01-2008-000-10131-0), AEBRC, and Yonsei University endowed to H. Kang.

\section{LITERATURE CITED}

Acosta-Martínez V, Cruz L, Sotomayor-Ramírez D, PérezAlegría L. 2007. Enzyme activities as affected by soil properties and land use in a tropical watershed. Appl Soil Ecol 35: 35-45.

Allison SD, Czimczik CI, Treseder KK. 2008. Microbial activity and soil respiration under nitrogen addition in Alaskan boreal forest. Global Change Biol 14: 1156-1168.

Anderson JM, Ingram JSI. 1993. Tropical Soil Biology and Fertility: A Handbook of Methods. $2^{\text {nd }}$ ed. C.A.B. International, Wallingford, pp 74-75.

Andersson S, Nilsson SI. 2001. Influence of $\mathrm{pH}$ and temperature on microbial activity, substrate availability of soilsolution bacteria and leaching of dissolved organic carbon in a mor humus. Soil Biol Biochem 33: 1181-1191.

Boerner REJ, Brinkman JA, Smith A. 2005. Seasonal variations in enzyme activity and organic carbon in soil of a burned and unburned hardwood forest. Soil Biol Biochem 37: 1419-1426.

Bonnett SAF, Ostle N, Freeman C. 2006. Seasonal variations in decomposition processes in a valley-bottom riparian peatland. Sci Total Environ 370: 561-573.

Enowashu E, Poll C, Lamersdorf N, Kandeler E. 2009. Microbial biomass and enzyme activities under reduced nitrogen deposition in a spruce forest soil. Appl Soil Ecol 43: 11-21.

Halvorson JJ, Smith JL, Papendick RI. 1996. Integration of multiple soil parameters to evaluate soil quality: a field example. Biol Fertil Soils 21: 207-214.

Harrison AF. 1983. Relationship between intensity of phosphatase activity and physico-chemical properties in woodland soils. Soil Biol Biochem 15: 93-99.

Haussling M, Marschner H. 1989. Organic and inorganic soil phosphates and acid phosphatase activity in the rhizosphere of 80-year-old Norway spruce (Picea abies (L.) Karst.) trees. Biol Fertil Soils 8: 128-133.

Hopkins DW, Sparrow AD, Elberling B, Gergorich EG, Novis PM, Greenfield LG, Tilston EL. 2006. Carbon, nitrogen and temperature controls on microbial activity in soils from an Antarctic dry valley. Soil Biol Biochem 38: 31303140 .

Jia B, Zhou G, Wang Y, Wang F, Wang X. 2006. Effects of temperature and soil water-content on soil respiration of grazed and ungrazed Leymus chinensis steppes, Inner Mongolia. J Arid Environ 67: 60-76.

Jin X, Wang S, Zhou Y. 2008. Microbial $\mathrm{CO}_{2}$ production from surface and subsurface soil as affected by temperature, moisture, and nitrogen fertilisation. Aust J Soil Res 46: 273-280.

Jordan D, Ponder F Jr, Hubbard VC. 2003. Effects of soil compaction, forest leaf litter and nitrogen fertilizer on two oak species and microbial activity. Appl Soil Ecol 23: 3341.

Kang H, Freeman C. 1999. Phosphatase and arylsulphatase activities in wetland soils: annual variation and controlling factors. Soil Biol Biochem 31: 449-454.

Kang H, Freeman C. 2009. Soil enzyme analysis for leaf litter decomposition in global wetlands. Commun Soil Sci Plan Anal 40: 3323-3334.

Kang H, Lee D. 1998. Changes of soil enzyme activities by simulated acid and nitrogen deposition. Chem Ecol 14: 123-131.

Kang SY, Doh S, Lee D, Lee D, Jin VL, Kimball JS. 2003. Topographic and climatic controls on soil respiration in six temperate mixed-hardwood forest slopes, Korea. Global Change Biol 9: 1427-1437.

Kennedy AC, Gewin VL. 1997. Soil microbial diversity: present and future considerations. Soil Sci 162: 607-617.

Keeney DR, Nelson DW. 1982. Indophenol-blue method. In: Methods of Soil Analysis: Part. 2. Chemical and Microbiologial Properties (Page AL, Milier RH, Keeney DR, 
eds). $2^{\text {nd }}$ ed. American Society of Agronomy, Madison, WI, pp 674-676.

Killham K, Staddon WJ. 2002. Bioindicators and sensors of soil health and the application of geostatistics. In: Enzymes in the Environment: Activity, Ecology, and Applications (Burns RG, Dick RP, eds). Marcel Dekker, New York, NY, pp 391-405.

Kourtev PS, Ehrenfeld JG, Haggblom M. 2002. Exotic plant species alter the microbial community structure and function in the soil. Ecology 83: 3152-3166.

Orchard VA, Cook FJ. 1983. Relationship between soil respiration and soil moisture. Soil Biol Biochem 15: 447-453.

Paul EA, Clark FE. 1989. Soil Microbiology and Biochemistry. Academic Press, New York, NY.

Sinsabaugh RL, Hill BH, Shah JJF. 2009. Ecoenzymatic stoichiometry of microbial organic nutrient acquisition in soil and sediment. Nature 462: 795-798.

Speir TW, Cowling JC. 1991. Phosphatase activities of pasture plants and soils: relationship with plant productivity and soil P fertility indices. Biol Fertil Soils 12: 189-194.

Speir TW, Ross DJ. 2002. Hydrolytic enzyme activities to assess soil degradation and recovery. In: Enzymes in the Environment: Activity, Ecology, and Applications (Burns RG, Dick RP, eds). Marcel Dekker, New York, NY, pp 407432.

Stark JM, Firestone MK. 1995. Mechanisms for soil moisture effects on activity of nitrifying bacteria. Appl Environ Microbiol 61: 218-221.

Trasar-Cepeda C, Leirós MC, Gil-Sotres F. 2000. Biochemical properties of acid soils under climax vegetation (Atlantic oakwood) in an area of the European temperate-humid zone (Galicia N.W. Spain): specific parameters. Soil Biol Biochem 32: 747-755.
Ushio M, Kitayama K, Balser TC. Tree species effects on soil enzyme activities through effects on soil physicochemical and microbial properties in a tropical montane forest on Mt. Kinabalu, Borneo. Pedobiology. (in press)

Vance ED, Chapin FS. 2001. Substrate limitations to microbial activity in taiga forest floors. Soil Biol Biochem 33: 173-188.

Waldrop MP, Balser TC, Firestone MK. 2000. Linking microbial community composition to function in a tropical soil. Soil Biol Biochem 32: 1837-1846.

Waring RH, Schlesinger WH. 1986. Forest Ecosystems: Concepts and Management. Academic Press, New York, NY.

Wellington EMH, Berry A, Krsek M. 2003. Resolving functional diversity in relation to microbial community structure in soil: exploiting genomics and stable isotope probing. Curr Opin Microbiol 6: 295-301.

Winkler JP, Cherry RS, Schlesinger WH. 1996. The $\mathrm{Q}_{10}$ relationship of microbial respiration in a temperate forest soil. Soil Biol Biochem 28: 1067-1072.

Wright AL, Reddy KR. 2001. Phosphorus loading effects on extracellular enzyme activities in Everglades Wetland Soils. Soil Sci Soc Am J 65: 588-595.

Ye R, Wright AL, Inglett K, Wang Y, Ogram AV, Reddy KR. 2009. Land-use effects on soil nutrient cycling and microbial community dynamics in the Everglades Agricultural Area, Florida. Commun Soil Sci Plant Anal 40: 27252742.

Zak JC, Willig MR, Moorhead DL, Wildman HG. 1994. Functional diversity of microbial communities: a quantitative approach. Soil Biol Biochem 26: 1101-1108. 